\title{
Deteksi Kematangan Daun Selada (Lactuca Sativa $L$ ) Berbasis Android Menggunakan Nilai RGB Citra
}

\author{
Khaironi Dwi Septiaji, Kartika Firdausy \\ Program Studi Teknik Elektro, Fakultas Teknologi Industri, Universitas Ahmad Dahlan \\ Kampus III, Jln. Prof. Dr. Soepomo, S.H Umbulharjo, Yogyakarta 55161 \\ e-mail: khaironi11@gmail.com, kartika@ee.uad.ac.id
}

\begin{abstract}
Lettuce is the popular vegetable because their have a color, a texture, and flavour which can be a food looks fresh. This kind of vegetables is grow up in a year, in other word that have life cycle within a year. In this paper, we are present the application design of the smartphone for the lettuce maturity detection based on Android using image RGB values in real time. This application is designed with the OpenCV library that can be use to detect a plant maturity condition by image processing. There are three condition used to parameter such as immature $(B M)$, mature (M), overly mature (TM) with range of $R G B$ value in variant condition. The sample is used image of 45 samples. The examination are conducted of three conditions using light intensity of 500 lux, 5000 lux, and 550 lux, then three distance variations of $10 \mathrm{~cm}, 15 \mathrm{~cm}$, and $20 \mathrm{~cm}$. The results are shown accuracy of $80 \%, 78 \%$, and $82 \%$.
\end{abstract}

Keywords: Lettuce; Image Processing; RGB; Android; OpenCV.

\begin{abstract}
Abstrak
Selada merupakan sayuran yang populer karena memiliki warna, tekstur, serta aroma yang menyegarkan tampilan makanan. Sayuran ini merupakan tanaman setahun atau tanaman yang menyelesaikan seluruh siklus hidupnya dalam rentang setahun. Pada paper ini, kami menyajikan perancangan aplikasi pada smartphone untuk deteksi kematangan tanaman selada berbasis Android menggunakan nilai $R G B$ citra secara real time. Aplikasi ini dirancang dengan menggunakan pustaka OpenCV yang dapat digunakan untuk mendeteksi kondisi tanaman dengan pengolahan citra. Ada tiga kondisi yang digunakan sebagai parameter yaitu belum matang (BM), matang (M) dan terlalu matang (TM) dengan rentang nilai $R G B$ untuk setiap kondisi berbeda-beda. Data yang digunakan sebanyak 45 sampel citra. Pengujian dilakukan dengan tiga kondisi intensitas cahaya 500 lux, 5000 lux, dan 550 lux, serta tiga variasi jarak 10 $\mathrm{cm}, 15 \mathrm{~cm}$, dan $20 \mathrm{~cm}$. Hasil pengujian menunjukkan akurasi sebesar $80 \%, 78 \%$, dan $82 \%$.
\end{abstract}

Kata kunci: Selada; Pengolahan Citra; RGB; Android; OpenCV.

\section{Pendahuluan}

Selada (Lactuca sativa L) adalah tanaman yang termasuk dalam famili Compositae [1]. Selada merupakan sayuran yang populer karena memiliki warna, tekstur, serta aroma yang menyegarkan tampilan makanan. Selada sering ditemukan sebagai bahan pelengkap pada makanan salad, kebab dan burger. Pada saat ini untuk proses panen yang biasa dilakukan berdasarkan usia tanaman, warna daun selada dan dengan cara mencicipi rasa dari selada. Proses panen berdasarkan usia tanaman terbagi tiga kondisi yaitu belum matang (umur 30-34 hari), matang (umur 35-50 hari), dan terlalu matang (umur 51-55 hari). Pendeteksian berdasarkan warna dari daun selada secara manual masih belum akurat karena mata manusia tidak dapat membedakan warna analogus (warna yang tampak mirip tetapi sebenarnya berbeda). Proses deteksi lainnya dilakukan dengan cara mencoba rasa selada, namun hal tersebut dapat merusak tekstur daun selada tersebut. Berdasarkan permasalahan yang ada diperlukan alat yang dapat mengidentifikasi kematangan daun selada dari tiga kondisi tanpa merusak tekstur dari daun selada menggunakan kamera Android dengan metode image processing. 
Pada penelitian yang dilakukan peneliti lain yakni objek yang di deteksi adalah mentimun dikembangkan untuk mendeteksi objek selada[2]. Deteksi objek menggunakan metode color blob detection dengan komposisi warna dari dan nilai $R G B$ [3-4]. Penelitian yang dilakukan digunakan sebagai referensi tambahan untuk pendeteksian objek menggunakan Android dapat di terapkan pada penelitian ini [5].

\section{Metode Penelitian}

\subsection{Dasar Teori}

\subsubsection{Citra}

Citra (image) adalah gambar pada bidang dwimatra (dua dimensi). Ditinjau dari sudut pandang matematis, citra merupakan fungsi menerus (continue) dari intensitas cahaya pada bidang dwimatra. Sumber cahaya menerangi objek, objek memantulkan kembali sebagian dari berkas cahaya tersebut. Pantulan cahaya ini ditangkap oleh oleh alat - alat optik, misalnya mata pada manusia, kamera, pemindai (scanner), dan sebagainya, sehingga bayangan objek yang disebut citra tersebut terekam [6].

\subsubsection{Citra Warna (True Color)}

Pada citra warna, setiap titik mempunyai warna yang spesifik yang merupakan kombinasi dari 3 warna dasar, yaitu: merah, hijau, dan biru. Format citra ini sering disebut sebagai citra $\mathrm{RGB}$ (red-green-blue). Setiap warna dasar mempunyai intensitas sendiri dengan nilai maksimum 255 (8 bit), misalnya warna kuning merupakan kombinasi warna merah dan hijau sehingga nilai RGB-nya adalah 255255 0; sedangkan warna ungu muda nilai RGB-nya adalah 1500150. Dengan demikian setiap titik pada citra warna membutuhkan data 3 byte[7].

\subsubsection{Blob Detection}

Blob detection atau deteksi blob yaitu mendeteksi kumpulan titik-titik piksel yang memiliki warna berbeda (lebih terang atau lebih gelap) dari latar belakang dan menyatukannya dalam suatu region. Dalam deteksi blob, algoritma yang dipakai adalah algoritma growing regions. Algoritma ini digunakan untuk menemukan blob di dalam gambar dan bisa diaplikasikan di sequence image. Konsep algoritma growing regions adalah menampilkan image sebagai matrik piksel dan nilai garis yang sudah pasti [8].

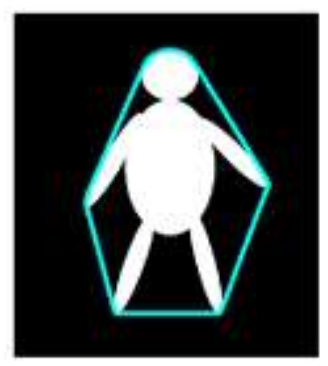

Gambar 1. Convex Hull

Convex Hull dari blob pada Gambar 1 adalah poligon cembung minimum yang berisi blob sesuai dengan penempatan karet gelang di sekitar blob. Hal ini dapat ditemukan dengan cara berikut, dari piksel paling atas pada pencarian blob ke kanan sepanjang garis horizontal. Jika tidak ada piksel blob yang ditemukan meningkat (searah jarum jam) pada sudut garis pencarian dan ulangi pencarian. Bila piksel blob ditemukan, baris pertama poligon didefinisikan dan pencarian baru dimulai berdasarkan sudut dari garis pencarian sebelumnya. Saat pencarian muncul kembali di piksel paling atas, convex hull telah selesai [9].

\subsubsection{Android}

Android adalah sistem operasi berbasis Linux bagi telepon seluler seperti telepon pintar dan komputer tablet. Android juga menyediakan platform terbuka bagi para pengembang untuk menciptakan aplikasi mereka sendiri yang akan digunakan untuk berbagai macam piranti gerak. Awalnya, Google Inc. membeli Android Inc., pendatang baru yang membuat piranti lunak untuk ponsel. kemudian dalam pengembangan Android, dibentuklah Open Handset Alliance, 
Jurnal IImu Teknik Elektro Komputer dan Informatika (JITEKI)

Vol. 4, No. 1, Juni 2018

konsorsium dari 34 perusahaan piranti keras, piranti lunak, dan telekomunikasi, termasuk Google, HTC, Intel, Motorola, Qualcomm, T-Mobile, dan Nvidia [10].

\subsection{Alat dan Bahan Penelitian}

\subsubsection{Alat Penelitian}

Alat penelitian yang digunakan terdiri dari hardware dan software. Hardware yang digunakan berupa Smartphone Android dengan sistem operasi Android versi 6.0 (Marshmallow) Chipset MediaTek MT6735 CPU Quad Core 1.3 GHz GPU Mali-T720 MP2. Software yang digunakan berupa sistem operasi windows 8.0 Pro, dan Eclipse IDE.

\subsubsection{Bahan Penelitian}

Bahan penelitian yang digunakan adalah Obyek citra yang terdiri dari 3 kategori selada yaitu belum matang, matang dan terlalu matang, dengan total 3 tanaman selada. Pengujian aplikasi dilakukan pada variasi intensitas cahaya dan variasi jarak digunakan 15 citra.

\subsection{Perancangan Sistem}

Perancangan sistem terdiri dari diagram blok dan diagram alir yang merupakan tahapan proses pengolahan citra secara real time pada saat kamera smartphone dalam kondisi aktif. Objek citra yang tertangkap akan ditampilkan pada layar smartphone.

\subsubsection{Diagram Blok Sistem}

Diagram blok sistem aplikasi deteksi kematangan tanaman selada menggunakan Android dapat dilihat pada Gambar 2.

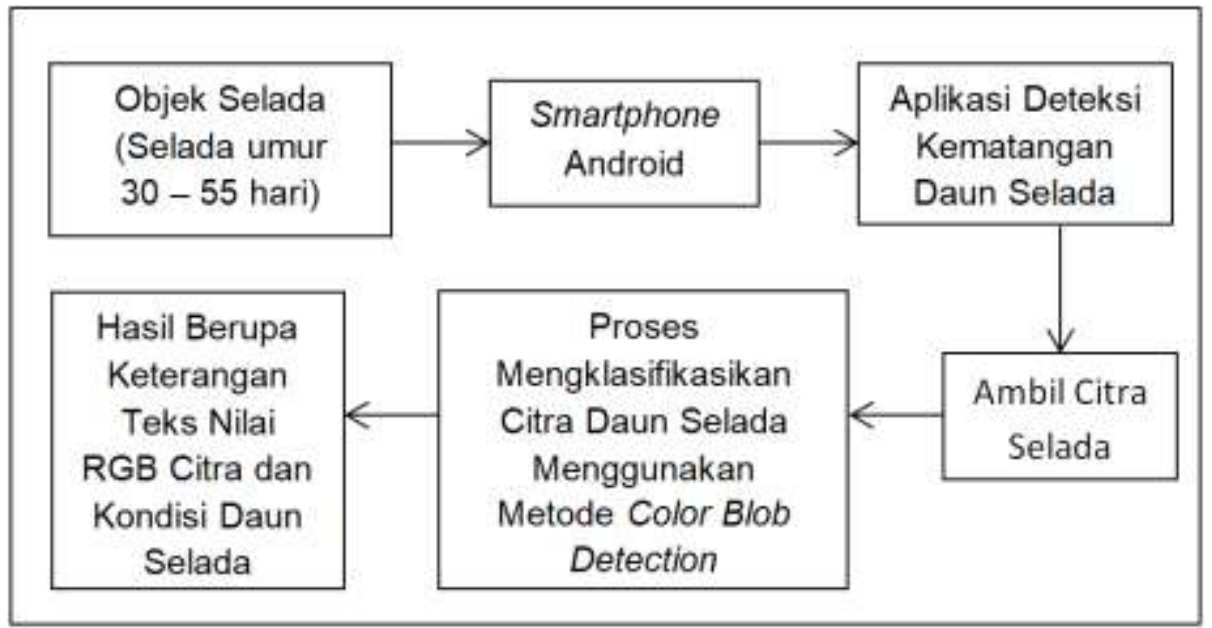

Gambar 2. Diagram blok sistem aplikasi deteksi kematangan tanaman selada

Tanaman selada yang berumur 30 - 55 hari diambil citranya menggunakan kamera pada smartphone Android melalui aplikasi deteksi kematangan tanaman selada menggunakan Android, selanjutnya user menyentuh objek pada layar smartphone, jika sudah didapatkan nilai warna yang sesuai maka proses color blob detection akan berjalan dan muncul tulisan "Nilai RGB" yang merupakan nilai komponen RGB (Red, Green, Blue) selada yang telah dilakukan proses onTouch sebelumnya. Selanjutnya tampilan teks nilai RGB hilang, kemudian muncul tulisan "Kondisi Selada" yaitu "Belum Matang", "Matang", atau "Terlalu Matang" sebagai komentar terhadap tingkat kematangan selada serta munculnya kontur dan kotak berwarna yang mengelilingi tepi-tepi objek pada layar smartphone, yang bertujuan memberikan informasi kepada user mengenai kondisi selada yang telah teridentifikasi. 
Jurnal IImu Teknik Elektro Komputer dan Informatika (JITEKI)

Vol. 4, No. 1, Juni 2018

\subsubsection{Diagram Alir Sistem}

Diagram alir yang ditunjukkan pada Gambar 3. Merupakan tahapan proses sistem secara keseluruhan aplikasi deteksi kematangan tanaman selada berdasarkan class ColorBlobActivity.java dan ColorBlobDetector.java.

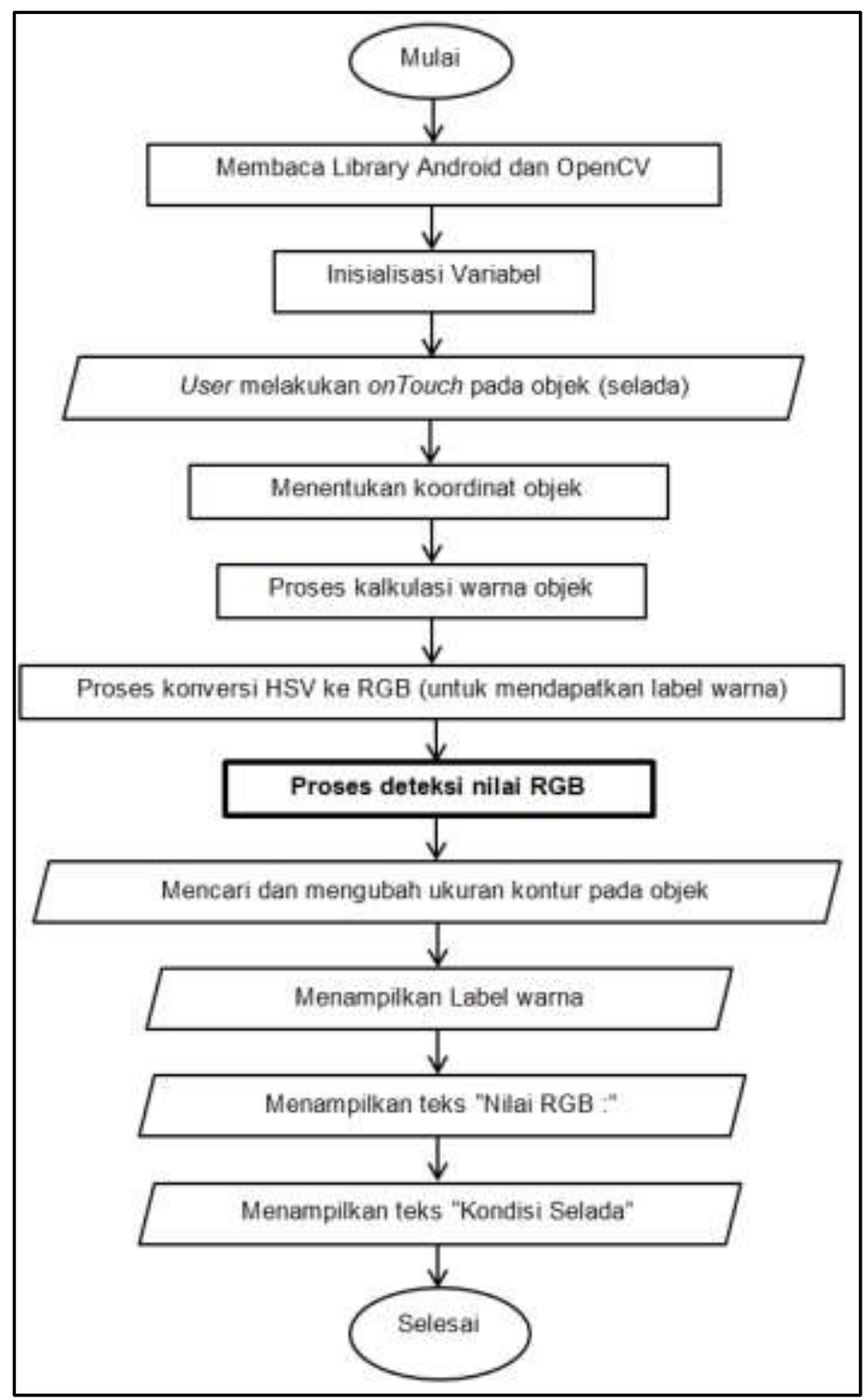

Gambar 3. Perancangan keseluruhan sistem aplikasi deteksi kematangan selada

Pada bagian pertama, class ColorBlobActivity.java berfungsi untuk membaca library android dan sebagai inisialisasi nilai serta besaran variabel yang akan digunakan. Pada saat user melakukan onTouch maka nilai RGB yang keluar. Bagian pertama juga berfungsi untuk menentukan koordinat serta ukuran objek dan kalkulasi warna pada objek untuk dilakukan proses selanjutnya yaitu proses untuk mendeteksi warna RGB, setiap kondisi selada memiliki rentang nilai RGB yang berbeda-beda.

Pada bagian kedua, class ColorBlobDetector .java. Variabel yang ditampilkan pada layar smartphone seperti kontur pada objek, label warna, teks/komentar dari kondisi tingkat kematangan selada dan nilai RGB. Proses Deteksi warna RGB ditunjukkan pada Gambar 4. 
Jurnal IImu Teknik Elektro Komputer dan Informatika (JITEKI)

Vol. 4, No. 1, Juni 2018

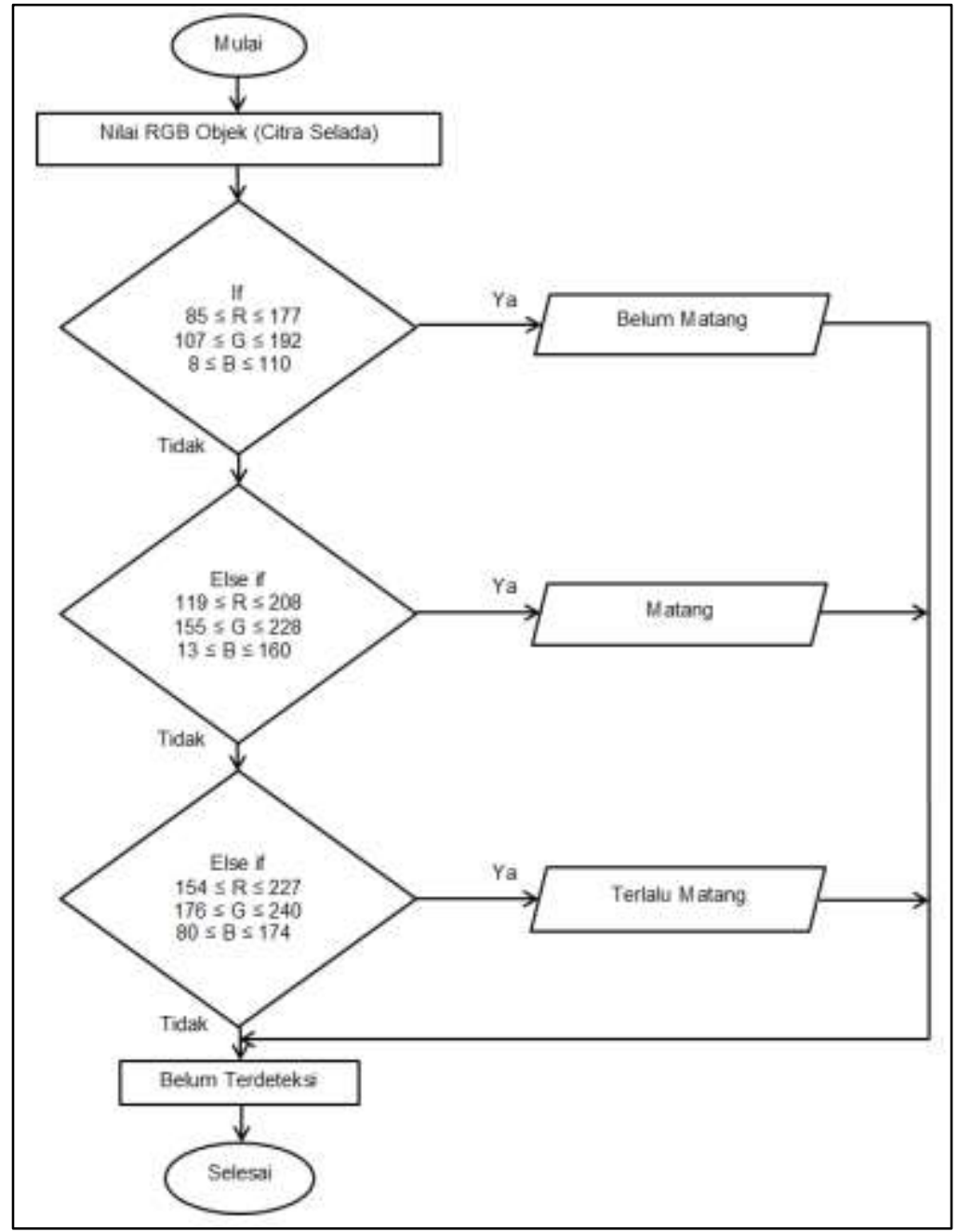

Gambar 4. Perancangan deteksi warna RGB

Tampilan aplikasi ditunjukkan pada Gambar 5.

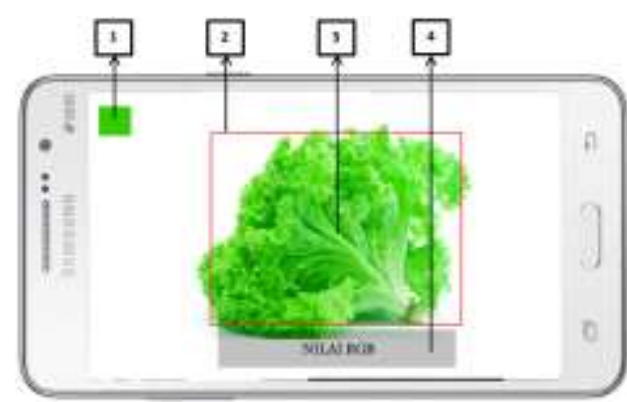

(a)

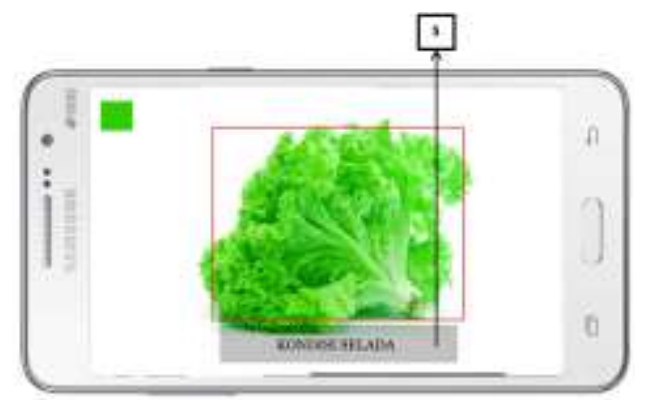

(b)

Gambar 5. Tampilan, aplikasi deteksi kematangan selada, (a) Nilai RGB, (b) Kondisi selada

Berdasarkan pentunjuk penomoran pada Gambar 5 berupa visualisasi tampilan aplikasi deteksi kematangan selada ditunjukkan pada Tabel 1. 
Jurnal IImu Teknik Elektro Komputer dan Informatika (JITEKI) Vol. 4, No. 1, Juni 2018

Tabel 1. Keterangan penomoran pada tampilan aplikasi

\begin{tabular}{cc}
\hline No & Keterangan \\
\hline 1 & Label warna \\
2 & Kotak kontur \\
3 & Citra objek \\
4 & Teks nilai RGB \\
5 & Teks hasil \\
\hline
\end{tabular}

Gambar 5 (a) merupakan tampilan aplikasi deteksi kematangan selada yang telah berjalan dan diarahkan pada objek selada. Proses color blob detection telah berjalan dengan melakukan proses onTouch pada selada, maka pada area dengan warna yang sama dengan area yang dikenakan onTouch akan terbentuk kontur secara otomatis dan menampilkan nilai RGB yang akan muncul sesuai dengan nilai RGB area selada yang dikenakan proses onTouch sebelumnya dan warna yang dilakukan onTouch akan terlihat pada label warna. Setiap tingkat kematangan selada memiliki rentang RGB yang berbeda-beda.

Gambar 5 (b) merupakan tampilan komentar berupa kondisi selada yaitu "Belum Matang (BM)", "Matang (M)", dan "Terlalu Matang (TM)". Aplikasi dapat mengidentifikasi tingkat kematangan selada berdasarkan rentang nilai RGB. Tampilan komentar kondisi selada muncul setelah tampilan nilai RGB.

Aplikasi deteksi kematangan selada akan menampilkan nilai RGB (Red, Green, Blue) dari objek (selada) yang dipilih dan setiap tingkat kematangan selada memiliki rentang RGB yang berbeda-beda. Untuk kondisi selada belum matang memiliki rentang RGB yaitu Red : 85-177, Green : 107-192, Blue : 8-110. Untuk selada matang memiliki rentang RGB yaitu Red: 119-208, Green : 155-228, Blue : 13-160, dan selada terlalu matang memiliki rentang RGB yaitu Red: 154-227, Green : 176-245, Blue : 80-174.

\section{Hasil dan Pembahasan}

\subsection{Pengujian Aplikasi}

Pengujian aplikasi deteksi kematangan selada terlihat pada Gambar 6.

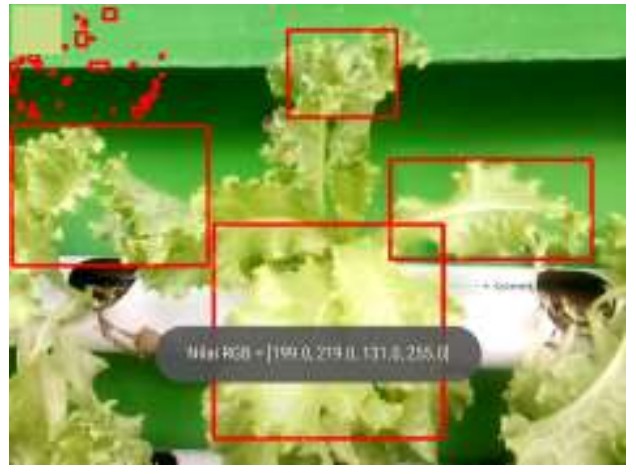

(a)

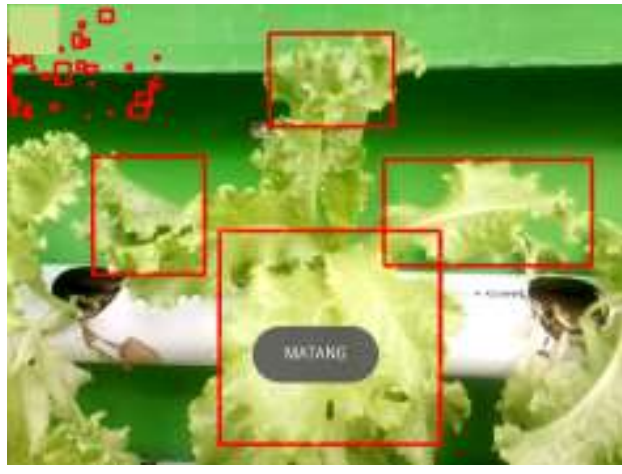

(b)

Gambar 6. Tampilan proses deteksi kematangan selada, (a) tampilan teks nilai RGB, (b) tampilan teks kondisi selada

Gambar 6 (a) merupakan tampilan nilai RGB dari selada matang pada area yang dilakukan proses onTouch akan ditampilkan kontur berbentuk kotak berwarna merah. Nilai RGB pada Gambar 6 adalah [199.0 219.0131 .0 255.0]. Nilai tersebut masuk ke dalam rentang nilai RGB selada matang, dengan Red $=199$, Green $=219$, Blue $=131$, Alpha $=255$. Alpha merupakan tambahan yang merujuk kepada alpha channel. Alpha channel merupakan metode untuk menentukan tingkat transparan sebuah warna. Nilai alpha selalu bernilai 255, maka warna tidak transparan atau tidak tembus pandang. Gambar 6 (b) merupakan tampilan komentar kondisi selada matang dan pada area yang dilakukan proses onTouch. Teks komentar yang ditampilkan yaitu "Matang" karena pada warna selada tersebut termasuk ke dalam rentang nilai RGB kondisi "Matang". 
Jurnal IImu Teknik Elektro Komputer dan Informatika (JITEKI) Vol. 4, No. 1, Juni 2018

\subsection{Hasil Pengujian Aplikasi}

Hasil pengujian aplikasi deteksi kematangan daun selada kondisi belum matang terlihat pada Tabel 2.

Tabel 2. Hasil pengujian aplikasi

\begin{tabular}{ccc}
\hline Jarak & Kondisi & $\begin{array}{c}\text { Jumlah terdeteksi } \\
\text { (per 15 citra) }\end{array}$ \\
\hline $10 \mathrm{~cm}$ & Belum Matang & 15 Citra \\
$10 \mathrm{~cm}$ & Matang & 9 Citra \\
$10 \mathrm{~cm}$ & Terlalu Matang & 12 Citra \\
$15 \mathrm{~cm}$ & Belum Matang & 14 Citra \\
$15 \mathrm{~cm}$ & Matang & 9 Citra \\
$15 \mathrm{~cm}$ & Terlalu Matang & 12 Citra \\
$20 \mathrm{~cm}$ & Belum Matang & 14 Citra \\
$20 \mathrm{~cm}$ & Matang & 13 Citra \\
$20 \mathrm{~cm}$ & Terlalu Matang & 10 Citra \\
\hline
\end{tabular}

Pada Tabel 2 merupakan hasil pengujian aplikasi deteksi kematangan daun selada. Setiap jarak dilakukan pengujian berdasarkan 3 variasi intensitas cahaya yaitu 500 lux (pagi hari), 5000 lux (sore hari) dan 550 lux (sore hari). Jarak $10 \mathrm{~cm}$, belum matang jumlah citra yang terdeteksi adalah 15 citra yang sesuai, kondisi matang jumlah citra yang terdeteksi adalah 9 citra yang sesuai dan 6 citra yang tidak sesuai, dan kondisi terlalu matang jumlah citra yang terdeteksi adalah 12 citra yang sesuai dan 3 citra yang tidak sesuai. Jarak $15 \mathrm{~cm}$, kondisi belum matang jumlah citra yang terdeteksi adalah 14 citra yang sesuai dan 1 citra yang tidak sesuai, kondisi matang jumlah citra yang terdeteksi adalah 9 citra yang sesuai dan 6 citra yang tidak sesuai, kondisi terlalu matang jumlah citra yang terdeteksi adalah 12 citra yang sesuai dan 3 citra yang tidak sesuai. Jarak $20 \mathrm{~cm}$, kondisi belum matang jumlah citra yang terdeteksi adalah 14 citra yang sesuai dan 1 citra yang tidak sesuai, kondisi matang jumlah citra yang terdeteksi adalah 13 citra yang sesuai dan 2 citra yang tidak sesuai, kondisi terlalu matang jumlah citra yang terdeteksi adalah 10 citra yang sesuai dan 5 citra yang tidak sesuai. Jadi, total citra yang sesuai pada jarak $10 \mathrm{~cm}$ sejumlah 36 citra, jarak $15 \mathrm{~cm}$ sejumlah 35 citra, dan jarak $20 \mathrm{~cm}$ sejumlah 37 citra. Pada Tabel 3 menunjukkan tingkat akurasi pengujian aplikasi, perolehan hasil akurasi berdasarkan persamaan (1).

Tabel 3. Akurasi hasil pengujian aplikasi

$$
\begin{array}{rc}
\hline \text { Jarak } & \text { Akurasi (\%) } \\
\hline 10 \mathrm{~cm} & 80 \\
15 \mathrm{~cm} & 78 \\
20 \mathrm{~cm} & 82 \\
\hline & \\
\text { Akurasi }(\%)=\frac{\text { Jumlah citra sesuai }}{\text { Total citra sampel }} \times 100 \%
\end{array}
$$

Jarak $10 \mathrm{~cm}$ jumlah citra sesuai adalah 36 citra dibagi total citra sampel yaitu 45 citra dikalikan dengan $100 \%$ didapatkan akurasi sebesar $80 \%$. Jarak $15 \mathrm{~cm}$ didapatkan akurasi sebesar $78 \%$, dan jarak $20 \mathrm{~cm}$ didapatkan akurasi sebesar $82 \%$.

\section{Kesimpulan}

Berdasarkan hasil pengujian aplikasi diperoleh tingkat keakurasian dari aplikasi pendeteksian kematangan selada dengan tingkat akurasi dengan tiga kondisi intensitas cahaya dan tiga variasi jarak $10 \mathrm{~cm}, 15 \mathrm{~cm}$, dan $20 \mathrm{~cm}$ sebesar $80 \%, 78 \%$, dan $82 \%$. sehingga dapat disimpulkan aplikasi ini dengan menggunakan motede color blob detection bekerja dengan baik. Aplikasi dapat diterapkan bagi petani untuk memudahkan pembudidayaan selada, khususnya pada saat proses panen. Diharapkan untuk penelitian selanjutnya dapat dikembangkan untuk mendeteksi lebih dari satu jenis tanaman dan diberikan fitur tambahan pada aplikasi deteksi kematangan selada untuk mempermudah penggunaan aplikasi. 
Jurnal IImu Teknik Elektro Komputer dan Informatika (JITEKI)

Vol. 4, No. 1, Juni 2018

\section{Referensi}

[1] Sunarjono, H. (2014). Bertanam 36 Jenis Sayur. Jakarta : Penebar Swadaya.

[2] Permadi, Y. (2014). Aplikasi Pengolahan Citra Untuk Identifikasi Kematangan Mentimun Berdasarkan Tekstur Kulit Buah Dengan Metode Ekstraksi Ciri Statistik. Yogyakarta. Universitas Ahmad Dahlan.

[3] Jatmika, S. \& Purnamasari, D. (2014). Rancang Bangun Alat Pendeteksi Kematangan Buah Apel Dengan Menggunakan Metode Image Processing Berdasarkan Komposisi Warna. Sekolah Tinggi Manajemen Informatika dan Komputer ASIA Malang, Vol. 8 No 1.

[4] Yesiansyah. (2016). Aplikasi Deteksi Kematangan Buah Sawit Menggunakan Metode Perbandingan Histogram Citra. Yogyakarta. Universitas Ahmad Dahlan.

[5] Candra, A.D. \& Fadlil, A. (2017). Sistem Penentuan Sudut Diam Granul Menggunakan Metode Pengolahan Citra Berbasis Android. Yogyakarta. Universitas Ahmad Dahlan. Vol. 3 No 2.

[6] Munir, Rinaldi. (2004). Pengolahan Citra Digital Dengan Pendekatan Algoritmik. Bandung: INFORMATIKA.

[7] Achmad, B. dan Firdausy, K. (2005). Teknik Pengolahan Citra Digital Menggunakan Delphi. Yogyakarta : Penerbit Ardi Publishing

[8] Kaspers, A. 2011. Blob detection. Biomedical Image Sciences Image Sciences Institute. Belanda : UMC Utrecht.

[9] Hassanien, A.E., \& Olivia, D.A., (2018). Advances in Soft Computing and Machine Learning in Image Processing. Switzerland : Springer.

[10] Safaat, N. (2012). Pemrograman Aplikasi Mobile Smarthphone dan Tablet PC Berbasis Android. Bandung : INFORMATIKA. 